\title{
Is There a More Promising Sector for Growth in (Less)-Innovative Economy?
}

\author{
Researcher, Dr.oec. Viktorija Šipilova \\ The Institute of Humanities and Social Sciences, Daugavpils University, Latvia \\ sipilova.viktorija@inbox.Iv \\ Associate Professor, Dr.oec. Elita Jermolajeva \\ Latvian Academy of Agricultural and Forestry Sciences, Latvia \\ elita.jermolajeva@gmail.com
}

\section{Doi:10.5901/mjss.2016.v7n3p171}

\begin{abstract}
The paper aims to find, which sectors mostly affect growth at different stages of innovative development and if these sectors differ for each stage. The authors contributes to the scientific and practical debates using the case study of the European Union and paying attention to different phases of innovative development, i.e. result (level of innovative development) and process (growth rates of innovative development) as well as to sectors' technological intensity. Employing of nonlinear regression loglog model and linear regression model provides evaluation of relationship between tested variables. The authors have found that sectors' impact on growth mostly differs between phases (i.e., between result and process of innovative development), rather than within them (i.e., across different stages of innovative development). Manufacturing significantly affects growth during the process of innovative development, especially, when economies are experiencing fast catching-up. However, economies boost specialization in all sectors of economic activity, even in low-tech and less knowledge-intensive, during the fastest improvements of level of innovative development as well. Services, in turn, affect growth at the phase of result mostly, especially, when economies are experiencing high level of innovative development. In general, authors have concluded that services affect growth in bigger extent in both phases of innovative development (result and process) and their technological intensity matters.
\end{abstract}

Keywords: (less)-innovative economy, economic growth, sectors of economic activity.

\section{Introduction}

A time, when economies are facing with the need clearly to understand the priorities and engines of the future growth, requires testing of sectors' previous contribution to growth in terms of innovative development. Lessons from the recent severe economic downturn have encouraged the searching for bottlenecks in the sectoral composition of economy (e.g. Radosevic, 2014) and focusing on only few key priorities that could lead to smart growth (European Commission, 2010, 2014). Differences across economies in terms of innovative performance, because of recent tendencies, are at the centre of scientific and practical debates. The paper aims to answer the question, which sectors mostly contribute to growth at different phases and stages of innovative development and whether these sectors differ. The research results could be of interest for scientists and practitioners in terms of 'smart' specialization strategies.

Economic growth, as an innovation-driven process (Dosi, Nelson, 2010), seems should have the same framework, i.e. innovative capacity, but different direction, i.e. specialization. In general, this means realization of 'smart' specialization strategies (European Commission, 2010, 2014). Smart growth requires activation and development of innovative entrepreneurship (e.g., Romano et al. 2014), in turn, the sectors for activation such entrepreneurship could be different (e.g., European Commission, 2010, 2014; McCann, Ortega-Argiles, 2015).

Additionally, scientific findings indicate that mostly economies that differ in terms of innovative activity and technological specialization converge (Maurseth, 2001) what can be positive for to the economies during catching-up. However, some scientists argue that catching-up economies have de-contextualized the usual innovation discourse (Karo, Kattel, 2011).

Despite of number of factors that affects growth (e.g. Coenen et al. 2015; Lerro, Jacobone, 2014; Tiits et al. 2015 etc.), authors focus only on sectors' contribution to growth, taking into account urgency of sectoral context and its absence in Innovation Union Scoreboard (IUS) (European Commission, 2015) as well as topicality of the structural changes in European economy.

The paper is organized as follows: the first section offers understanding of perception of sectors regarding their 
technological intensity and their possible impact on growth; the second chapter considers data, method and logic of research; the third chapter analyses the data and discovers the sectors' impact on growth at different stages of innovative development within two phases (result and process); finally, the fourth chapter concludes the paper and sets questions for the future research.

\section{Searching The 'Correct' Growth-Boosting Sector: Literature Background}

Conditions of single market and increasing competition contributes to rising of similarity between economic structures in Europe (Marelli, 2004) with exclusive focusing on high-technology sectors (McCann, Ortega-Argiles, 2015). Besides prioritizing high-technology sectors, the cases of regions and application of new technologies to sectors that are traditional for regional economy with exclusive focusing on local needs and priorities is the way for minimising negative consequences of 'regional innovation paradox' in European regions (McCann, Ortega-Argiles, 2015; Ali A.K., 2014; Muscio et al. 2015). Although, empirical research findings underline that fast growing sectors usually are high-tech also (Laursen, 1998).

The new approaches for overcoming low economic performance in Europe relate to specialization and growth that are unified under the term 'smart' (Naldi et al. 2015). Scientific findings indicate that definition 'smart' in terms of specialization and growth means to make a 'right' choice for employing resources (Kemeny, Storper, 2015). How regional economies can make a 'right' choice?

Specialization, as Marelli (2004) underlines, is significant factor for growth, but the development level of economy matters as well (Marelli, 2004). Mostly, despite of high relevance of service-based innovations, industrial sector and particularly manufacturing still is considered as an engine for economic growth (Kaldor, 1966; Marelli, 2004; Gallego, Marroto, 2015) and favourable specialization (and diversification also) mostly relates to tradable sector of economy what is explained by patterns of trade and growth of external demand (Kemeny, Stroper, 2015).

On the other hand, scientists consider specialization in knowledge intensive business services as significant prerequisite for regional growth, because, mostly, knowledge intensive business services provide positive knowledge spillovers on other economic actors and are crucial for regional innovation systems (Gallego, Marotto, 2015). However, scholars found negative effect from services on 'smart' specialization and growth also. For example, Fritsch and Slavtchev (2011) indicate on relatively low patent intensity in services. On the other hand, modern high-tech services become a part of manufacturing (e.g. Thakur, 2011) and thus actively participate in acceleration of economic growth.

Thus, economies that are far from world's leaders by innovation and quality in production as well as small economies are challenged by making the choice of 'right' specialization (e.g. Kemeny, Stroper, 2015,), which would be more promising for growth. Moreover, the choice in favour to certain sector(-s) of economic activity depends on stage of economic development as empirical research findings indicate. For example, Quatraro (2009) found that highly developed industrial regions are able to raise knowledge-based activity in each sector. In turn, catching-up regions concentrate innovative capacity in manufacturing sector. Additionally, employment in manufacturing seriously affects growth of GDP per capita (UNIDO, UNU-MERIT, 2012), what is of high significance especially for lower developed economies.

Moreover, empirical evidence of case studies underlines difficulty of the choice of 'right' specialization. For example, the cases of the biofuel energy in Sweden (Coenen et al. 2015) and the Italian National Energy Technological District (Lerro, Jacobone, 2014) shows that besides technologies, such factors as demand characteristics as well as business, geographical and institutional factors (Coenen et al. 2015; Lerro, Jacobone, 2014) should be taken into account during the choosing the 'right' specialization. Additionally, the case study of Balkan regions underlines that usually a lack of awareness at regional level and innovation culture hinders effective 'risk-sharing' and establishing knowledge-based activities for future growth in economically less developed regions with modest innovative performance (Huggins, Strakova, 2012). Therefore, leading positions of high-tech sectors in European economies depend on complex activities within the smart specialization concept (Tiits et al. 2015). Thus, activities to be smart in terms of specialization and growth are obligatory requirements for receiving financial aid from European Structural and Investment Funds in the field of innovation (Landabaso, 2014).

In addition, Fritsch and Slavtchev (2011) using the German case study found that innovation activity could be efficient in the peripheral regions of country also, although, R\&D activities are less efficient in the rural areas. Spatial characteristics of regional production structures indicate on role of large cities that work towards development of specialization in new directions taking into account possibilities to develop new activities, innovations etc. (O'Donoghue, Townshend, 2005) or high-tech accelerators to commercialise the ideas quickly (KPMG, 2015).

Finally, as Landabaso (2012) indicates, economies, which develop smart specialization, do not have universal 
advice or set of sectors. This process requires avoiding of imitation and focusing on already strong or promising sectors, which could gain from innovation. Possibilities of growth through innovation and with only few key priorities even outside high-tech sectors can boost the growth in all regions in Europe (Landabaso, 2012; European Commission, 2010; 2014). Avoiding of brightly expressed contradictions between high-tech and low-tech and medium-tech sectors, smart specialization is focusing on comparative advantages of each economy (European Commission, 2014).

The recent requirements for boosting growth in Europe provide the basis for understanding the empirical findings, when one might want to know the sectors that mostly contribute to 'smart' growth. Economic growth and, particularly, 'smart' growth depends on the number of factors and requirements mentioned in the chapter 2. The authors in the article, firstly, pay attention to the technological intensity of the sectors and their different contribution to growth in economies that are at different phases and stages of innovative development.

\section{Data, Method and Design of the Research}

Taking into account high disparities by innovative performance documented in the IUS (European Commission, 2015), comparative similarity by sectoral composition of economy and recent modest forecasts for the future economic growth in the EU, the data on sectors of economic activities are crucial for explaining growth performance and answering the question - is there a more promising sector for growth in economies that are at different phases and stages of innovative development?

As far as the IUS do not include the data on sectors of economic activities, it is hard to understand, whether and how the high and/or increasing innovative performance contributes to economic growth. This makes obvious the design of the research.

Firstly, authors use employment as independent variable in analysis, because the aim set for the paper requires presenting of sectoral composition of economy. As far as data on value added are not fully available for all branches and countries involved in the analysis, authors use only employment data. Moreover, in terms of specialization, employment data are necessary. Analysis covers 64 branches of economic activity in accordance with NACE 2. Rev. merged into 10 sectors depending on technological intensity (Eurostat, 2014) (see Appendix A for abbreviations used in the article for sectors of economic activity).

Sectoral composition of economy is presented, first, using the simple shares of employment and, second, using the relative specialization calculating Location Quotient $(L Q)$ that is widely spread in scientific contributions (e.g. Noseleit, 2015; Gallego, Maroto, 2015; Weterings, Marsili, 2015) and LQ's changes calculating $\Delta$ LQ from 2000 to 2011. The end of the period analysed (the year 2011) depends on statistical data availability for sectors of economic activity.

Secondly, authors consider sectors' contribution to growth in countries that are at different stages and phases of innovative development in accordance with data of IUS (European Commission, 2015). Authors understand stages of innovative development as follows - Leaders, Followers, Moderate and Modest (European Commission, 2015) and phases of innovative development as result (Innovation Index in 2014) and as process (growth rates of Innovation Index from 2007 to 2014) (European Commission, 2015) (see Appendix B and Appendix C for detailed classification). Such differentiation of countries using data on IUS (European Commission, 2015) symbolizes (less)-innovative economy. Each phase covers all four stages of innovative development.

Differentiated time series for regression analysis and for determination of stages and phases of innovative development were caused by data limitations. However, usual time lag between innovative activities and their effect (e.g. Badunenko, Fritsch, Stephan (2006) concluded this for effect of R\&D intensity on firms' technical efficiency) allow authors to assume that countries have pre-conditions for being at certain stage and phase of innovative development and that the certain positions should have long-time preparations and long-lasting effect.

Thirdly, authors estimate impact of sectors on economic growth at each stage and phase of innovative development using two complimentary regression models (nonlinear, particularly log-log model (1) and linear (2)) based on data on GDP per capita and sectoral employment for the time from 2000 to 2011:

$y\left(G D P\right.$ per capita) $=\beta_{0} x^{\beta_{1}}$

where $y$-dependent variable, $x$ - independent variable, $\beta$-coefficients of the regression equation, $i$ means sectors of economic activities

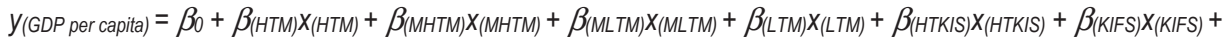

$\beta_{(K I M S) X_{(K I M S)}+\beta_{(O K I S)} x_{(O K I S)}+\beta_{(L K I M S)} x_{(L K I M S)}+\beta_{(O L K I S)} x_{(O L K I S)}}$

where $y$-dependent variable, $x$ - independent variable, $\beta$ - coefficients of the regression function

Estimation of interaction between dependent variable $(y)$ and independent variable(-s) $(x)$ is organized and 
numerical results are explained as suggested for social sciences in the scientific literature (e.g. Arhipova, Bālina, 2003).

The first is nonlinear regression model (log-log) that allows authors to calculate growth rates of GDP per capita as result of $1.00 \%$ employment growth in each sector of economic activity. The findings numerically characterize sectors' contribution to growth.

The second is linear regression model that offers possibility to select those sectors, which mostly contribute to growth and characterize relationship between tested variables qualitatively. Authors use stepwise method for linear regression.

GDP per capita, i.e. $y$, is dependent variable and number of independent (explanatory) variables $x_{i}$ means employment in each of ten sectors of economic activity.

Additionally, trends of high-tech and low-tech sectors in economies with different stages and phases of innovative development hold the interest to understand the benefits [to growth] from improvements of innovative performance. The research results will offer the knowledge for development of smart specialization strategies for economies that are at different phases and stages of innovative development.

\section{Research Results}

The choice in favour to high-tech sectors or in favour to an innovative activity in each sector despite sector's technological intensity takes place in recent scientific and practical debates. This means that economies are not able to prefer high-tech or low-tech sector because of their technological intensity only. This, in turn, makes difficult understanding of priorities necessary for the future growth. However, dividing of economies at different phases and stages of innovative development brings clearness to the analysis. New view on innovative performance of economies in context of sectoral employment allows authors to check, whether sectors that mostly contribute to growth differ across economies at each phase and each stage of innovative development.

The data on sectoral composition of economies indicate on low shares of high-tech and knowledge intensive sectors (as HTM and HTKIS), overall domination of less knowledge intensive services over manufacturing and predominance of low-tech manufacturing over high-tech manufacturing. Peculiarities mentioned above and relative similarity of sectoral composition of economy as well find evidence in all economies despite the stage of innovative development at both phases (see Table 1).

For example, LTM sector reaches the highest share in manufacturing despite the stage of innovative development (except Leaders (by result)). Values vary significantly, although, from $4.0 \%$ at the stage Followers (by result) to $15.0 \%$ at the stage Modest (by result) (see Table 1). Despite of difference in more than three times between the lowest and the highest shares, dominant position of LTM sector brightly characterizes overall sectoral composition of manufacturing. LKIMS sector provides similar tendencies in terms of services. The sector has dominant positions at all stages of innovative development and reaches maximal values at the stage Modest (by result) and Leaders (by process). The authors have found, although, differences by sectoral composition between the stages as well. Mostly, economies differ by share of the sector KIMS (see Table 1).

Table 1 - Sectoral composition of economy in EU in 2011, employment data

\begin{tabular}{|c|c|c|c|c|c|c|c|c|c|c|c|c|c|c|c|c|}
\hline & \multicolumn{8}{|c|}{ RESULT } & \multicolumn{8}{|c|}{ PROCESS } \\
\hline & \multicolumn{2}{|c|}{ Leaders } & \multicolumn{2}{|c|}{ Followers } & \multicolumn{2}{|c|}{ Moderate } & \multicolumn{2}{|c|}{ Modest } & \multicolumn{2}{|c|}{ Leaders } & \multicolumn{2}{|c|}{ Followers } & \multicolumn{2}{|c|}{ Moderate } & \multicolumn{2}{|c|}{ Modest } \\
\hline & $\%$ & LQ & $\%$ & LQ & $\%$ & LQ & $\%$ & LQ & $\%$ & LQ & $\%$ & LQ & $\%$ & LQ & $\%$ & LQ \\
\hline HTM & 2,0 & 0,76 & 1,0 & 1,35 & 1,0 & 1,32 & 1,0 & 0,84 & 1,0 & 1,02 & 1,0 & 0,89 & 1,0 & 1,21 & 1,0 & 0,99 \\
\hline MHTM & 7,0 & 0,58 & 3,0 & 1,50 & 5,0 & 1,33 & 5,0 & 1,16 & 6,0 & 1,31 & 3,0 & 0,72 & 6,0 & 1,37 & 5,0 & 1,0 \\
\hline MLTM & 5,0 & 0,69 & 3,0 & 1,03 & 6,0 & 1,47 & 7,0 & 1,33 & 7,0 & 1,47 & 4,0 & 0,87 & 6,0 & 1,12 & 3,0 & 0,65 \\
\hline LTM & 5,0 & 0,69 & 4,0 & 0,80 & 9,0 & 1,80 & 15,0 & 2,34 & 11,0 & 1,73 & 6,0 & 0,90 & 7,0 & 1,04 & 11,0 & 1,72 \\
\hline HTKIS & 3,0 & 1,14 & 4,0 & 0,95 & 2,0 & 0,98 & 3,0 & 0,79 & 3,0 & 0,93 & 3,0 & 1,11 & 3,0 & 0,90 & 1,0 & 0,31 \\
\hline KIFS & 3,0 & 1,17 & 4,0 & 0,99 & 2,0 & 1,00 & 2,0 & 0,66 & 2,0 & 0,74 & 3,0 & 1,09 & 3,0 & 1,00 & 1,0 & 0,38 \\
\hline KIMS & 9,0 & 1,22 & 10,0 & 1,07 & 6,0 & 0,83 & 4,0 & 0,42 & 6,0 & 0,68 & 10,0 & 1,12 & 8,0 & 0,95 & 2,0 & 0,20 \\
\hline OKIS & 29,0 & 1,12 & 33,0 & 0,97 & 29,0 & 1,22 & 23,0 & 0,79 & 25,0 & 0,84 & 31,0 & 1,05 & 28,0 & 0,96 & 40,0 & 1,36 \\
\hline LKIMS & 30,0 & 0,97 & 33,0 & 0,91 & 33,0 & 1,22 & 37,0 & 1,12 & 36,0 & 1,09 & 33,0 & 0,99 & 32,0 & 0,97 & 28,0 & 0,86 \\
\hline OLKIS & 7,0 & 0,78 & 5,0 & 1,15 & 7,0 & 1,54 & 3,0 & 0,58 & 3,0 & 1,02 & 6,0 & 0,89 & 6,0 & 1,21 & 8,0 & 0,99 \\
\hline
\end{tabular}

Notes: \% - share of the sector in economy, $L Q$ - specialization; Dark cells indicate on the highest shares of sectors within manufacturing and services and on the $L Q>1.00$. Explanation of sectors' abbreviations is available in the Appendix $A$

Source: authors' calculations based on Eurostat 2015b 
However, the data on sectors' share do not ensure complete understanding of sectors' meaning in economies. Therefore, the authors use data on specialization providing by the LQ calculations. The calculations discover valuable characteristics and indicate on differences across countries at different stages of innovative development. For example, the Leaders (by result), innovative performance of which is the aim for all, have pronounced specialization (LQ>1.00) for high-tech (HTKIS) and knowledge intensive (KIFS, KIMS, OKIS) services and weakly specialize in manufacturing. The Followers (by process) demonstrate such specialization as well. Countries that are at other stages of innovative development have more differentiated specialization, especially in manufacturing. The Moderate (by result), Leaders (by process) and Moderate (by process) reach $L Q>1.00$ in all manufacturing sectors. The Modest (by result) reaches the highest LQ value (2.34) for LTM sector.

Differentiated data on specialization across different stages of innovative development at phases of result and process allow authors to suppose that economies mostly specialize in manufacturing during the fast catching-up (see Table 1 on data for Leaders (by process)) and in services, when the desired high innovative performance is reached already (see Table 1 on data for Leaders (by result)).

Additionally, authors can find the sectors, which have high share in economy and LQ>1.00 at the same time. This means that such sectors as MLTM, LTM and OKIS (see Table 1) significantly contribute to economies and technologically less intensive manufacturing plays special role here.

Combination of data offered in the Table 1, although, does not characterize sectoral peculiarities of economies sufficiently for answering the question set for the research. Therefore, authors pay attention to the changes in specialization. $\Delta \mathrm{LQ}$ values add knowledge about sectoral composition of economy in terms of possible priorities set (by market forces and by strategies) in economies at different stages of innovative development.

The most valuable observation (see Table 2) highlights that the Leaders (by result) have cut specialization in all sectors, but the Leaders (by process) have raised specialization in all sectors (except the sector OKIS). Relatively low $\Delta \mathrm{LQ}$ values, although, reflect weakening of specialization across all sectors in the Leaders (by result). 'Medium' segment of manufacturing and market-oriented knowledge-intensive services have showed the highest fall about 0.102-0.124 points (see Table 2). In turn, higher $\Delta \mathrm{LQ}$ values have accompanied the process of strengthening of specialization at the stage Leaders (by process). Data variation from 0.110 to 0.550 points indicates on the different meaning of the sectors in economy as well. Authors have found that the Leaders (by process) have increased specialization in HTM and HTKIS sectors. However, the sector OLKIS with increasing specialization (+0.550 points) continues domination. The characterization of the data calculated, therefore, can indicate on some unfavourable tendencies for both innovative and less-innovative economies.

Table 2 - Changes of specialization in EU at different stages of innovative development, $\Delta \mathrm{LQ}$ values, 2000-2011

\begin{tabular}{|c|c|c|c|c||c|c|c|c|}
\hline & \multicolumn{9}{|c||}{ RESULT } & \multicolumn{5}{c|}{ PROCESS } \\
\hline & Leaders & Followers & Moderate & Modest & Leaders & Followers & Moderate & Modest \\
\hline HTM & $-0,080$ & 0,134 & 0,053 & $-0,372$ & 0,140 & $-0,056$ & 0,089 & $-0,250$ \\
\hline MHTM & $-0,109$ & 0,092 & 0,370 & $-0,146$ & 0,226 & $-0,039$ & 0,046 & $-0,222$ \\
\hline MLTM & $-0,102$ & 0,049 & 0,442 & $-0,032$ & 0,153 & $-0,038$ & 0,154 & $-0,065$ \\
\hline LTM & $-0,044$ & 0,031 & 0,427 & 0,161 & 0,016 & $-0,019$ & 0,243 & $-0,071$ \\
\hline \hline HTKIS & $-0,023$ & $-0,026$ & 0,025 & $-0,086$ & 0,155 & 0,001 & $-0,050$ & $-0,789$ \\
\hline KIFS & $-0,016$ & $-0,093$ & 0,266 & 0,126 & 0,126 & 0,014 & $-0,087$ & 0,024 \\
\hline KIMS & $-0,124$ & 0,182 & 0,137 & 0,030 & 0,110 & $-0,069$ & 0,059 & $-0,016$ \\
\hline OKIS & 0,030 & $-0,035$ & 0,212 & 0,013 & $-0,108$ & 0,008 & $-0,018$ & 0,154 \\
\hline LKIMS & $-0,028$ & $-0,059$ & 0,272 & 0,093 & 0,055 & $-0,004$ & $-0,037$ & 0,091 \\
\hline OLKIS & $-0,078$ & $-0,054$ & 0,294 & $-0,026$ & 0,550 & $-0,104$ & 0,027 & $-0,361$ \\
\hline
\end{tabular}

Note: Dark cells indicate on $\triangle L Q$ for sectors, which have reached $L Q>1.00$

Explanation of sectors' abbreviations is available in the Appendix $A$

Source: authors' calculations based on Eurostat 2015b

First, it is difficult to detect similar tendencies for economies with similar stages of innovative development. Second, not only less-innovative, but also innovative economies decrease specialization in high-tech and knowledge intensive activities. Additionally, the data calculated partly demonstrate that economy with high result of innovative performance has tendency to weakening specialization in high-tech and knowledge intensive services. Moreover, economies with fast improvements of innovative performance contribute to rising of low-tech and less knowledge intensive specialization. The 
scientific interest calls for testing the above-mentioned tendencies through assessment of sectors' impact on growth.

Combination of the data of Table 1 and Table 2 provides preliminary understanding of meaning of sectors of economic activity. The data on sectors' share in 2011 and changes in specialization during the 12 years have discovered that mostly non-dominant sectors (by share) have experienced brighter changes in specialization. Additionally, there is little difference between high-tech and knowledge intensive activities and those with opposite characteristics. Both 'poles', mostly have reached $\Delta \mathrm{LQ}<0.10$ in both innovative and less-innovative economies. This could mean a similar significance of all sectors despite the stage of innovative development.

Strong correlation between specialization and GDP per capita seriously reinforces the meaning of sectors' contribution to growth (see Table 3).

Table 3 - Correlation between specialization (LQ values) and growth (GDP per capita)

\begin{tabular}{|c|c|c|c|c|c|c|c|c|}
\hline & \multicolumn{4}{|c|}{ RESULT } & \multicolumn{4}{|c|}{ PROCESS } \\
\hline & Leaders & Followers & Moderate & Modest & Leaders & Followers & Moderate & Modest \\
\hline HTM & $.629^{\star}$ & $-.834^{\star *}$ & .549 & .198 & $.964^{\star *}$ & $-.558^{\star \star}$ & $.792^{\star \star}$ & -.356 \\
\hline MHTM & & $53^{* \star}$ & $.880^{* *}$ & $353^{* \star}$ & & $727^{* *}$ & & $.788^{\star \star}$ \\
\hline MLTM & .10 & $50^{\star \star}$ & $.959 * *$ & $-.790^{\star \star}$ & & $-.648^{*}$ & .24 & $.925^{\star \star}$ \\
\hline LTM & -.453 & $-.930^{\star \star}$ & -.224 & -.014 & $-.746^{\star \star}$ & $-.904^{\star \star}$ & -.202 & $-.605^{*}$ \\
\hline HTKIS & $650^{*}$ & 273 & -.224 & .254 & & 241 & .403 & -.043 \\
\hline & & 61 & $.856^{* *}$ & $.858^{\star *}$ & & $.802^{\star *}$ & & 039 \\
\hline KIMS & $.863^{\star *}$ & -157 & -.497 & $.767^{\star *}$ & $.806^{\circ}$ & .405 & $.940^{* *}$ & -.334 \\
\hline OKIS & & $.866^{* *}$ & $894^{* *}$ & $.706^{*}$ & $-.923^{\star *}$ & $.663^{*}$ & $-.684^{*}$ & $.660^{*}$ \\
\hline LKIMS & $-.822^{\star \star}$ & -.548 & $.932^{\star *}$ & $.638^{*}$ & $.806^{\star *}$ & -.205 & $-.914^{\star \star}$ & $.736^{* \star}$ \\
\hline OLKIS & .384 & -.575 & $-.614^{*}$ & -.275 & $.757^{\star *}$ & $.762^{\star *}$ & $.674^{\star}$ & .460 \\
\hline
\end{tabular}

Notes: Dark cells indicate on statistically significant correlation coefficients for sectors, which have $\Delta L Q>1.00$ (see Table 2); Pearson correlation; * correlation is significant at $0.05 ;{ }^{* *}$ correlation is significant at $0.01 ; n=12, n$-years (from 2000 to 2011). Explanation of sectors' abbreviations is available in the Appendix A

Source: authors' calculations based on Eurostat 2015a, 2015b

The data marked (see Table 3) indicate on the sectors, which have experienced brighter expressed changes in specialization and additionally have statistically significant close and medium close linkage with GDP per capita. As authors can see, brightly expressed changes in specialization mostly have linkage with GDP per capita during fast improvements of innovative performance (Leaders (by process)) or in case of moderate and modest result (Moderate (by result), Modest (by result)) in innovative performance. Leaders (by result) and Followers (by result) have experienced weak linkage between specialization and GDP per capita. Authors observe the same tendency for moderate and modest process of innovative development (Moderate (by process), Modest (by process)). In general, authors have found the opposite tendencies for economies that are at phases of result and process of innovative development.

Analysis of the data calculated [for understanding the sectors' meaning for growth at each stage of innovative development] one more time highlights that specialization is more significant for economy, when it experiences fast catching-up and/or demonstrate moderate and modest results in innovative performance. All sectors are important at these stages.

To characterize the meaning of sectors' at each stage of innovative development, authors have summarized the most important conclusions from the dataset analysis and calculations provided in the Tables 1, 2 and 3. The observations are as follows:

- Sectoral composition of economy is similar mostly at all stages of innovative development.

- In turn, specialization differs, especially between Leaders (by result) and Leaders (by process). Leaders (by result) specialize in services whilst Leaders (by process) specializes in manufacturing. These findings allow authors to suppose that economies mostly specialize in manufacturing during the fast catching-up and in services, when the desired high innovative performance is reached (see Table 1).

- Specialization has statistically significant close linkage with GDP per capita for economies with fast improvements of innovative performance (process) or moderate, modest results. Moreover, it looks that specialization is important in lesser extent for Leaders (by result) and Followers (by result), as well as for Moderate (by process) and Modest (by process). 
- As a result, the Leaders (by result) decrease specialization in all sectors, but the Leaders (by process) increase specialization in all sectors (except the sector OKIS).

The data analysed hold the supposition that sectors that mostly contribute to growth differ between economies depending on phase of innovative development, i.e. result and process of innovative development. The next step is to find sectors' contribution to growth at each stage of innovative development within the phases of result and process.

First, the authors have developed a number of regression log-log models for each sector at each stage of innovative development to determine and characterize sectors' contribution to growth using the data on GDP per capita and employment in 10 sectors of economic activity. The main findings provide the knowledge about growth rate of GDP per capita as result of $1.00 \%$ growth of employment in each sector (see Table 4, Appendix D).

Results of calculations presented in the Table 4 indicate that there are sectors, the growth of employment of which reduces GDP per capita. Mostly this occurs in economies that experience high level (result) or slow rate (process) of innovative development (e.g. Leaders (by result), Followers (by result) and Moderate (by process)). The observation is topical for all manufacturing sectors (except MLTM) and the sector KIFS in services. Additionally, fall of GDP per capita as result of $1.00 \%$ employment growth in KIFS reaches higher values than in case of employment growth in manufacturing. As authors can see from the statistically significant models, the sector LTM in manufacturing is unfavourable for growth. Additionally, the data is not statistically significant in most cases for this sector.

Significant growth of GDP per capita (from $0.483 \%$ to $1.705 \%$ ) as result of $1.00 \%$ employment growth can be reached during the fast catching-up and not during the experiencing the high performance of innovative development. Economies that are at the high stage of innovative development can reach growth of GDP per capita, which vary from $0.273 \%$ to $1.444 \%$. In turn, GDP per capita growth in economies that have lower level of result and slower process of innovative development has experienced growth rates that were higher. Additionally, several sectors has participated in formation of GDP per capita. In general, employment increase in amount of $1.00 \%$ in services and especially in less knowledge-intensive services seriously contributes to the growth of GDP per capita both in innovative and less-innovative economies.

Employment growth in manufacturing rarely contributes to growth of GDP per capita as authors can see from statistically significant models (see Table 4). The economies that are at stages Moderate (result) and Leaders (process) have demonstrated this only. Moreover, the economies that are at stage Moderate (result) have reached significant growth of GDP per capita (from $0.472 \%$ to $0.715 \%$ ) (except LTM sector) only. In turn, economies that are at stage Leaders (process) have reached growth of GDP per capita in amount of $1.705 \%$ thanks to $1.00 \%$ employment growth in MHTM sector accordingly to calculations made by the authors. Taking into account statistically insignificant models, authors have seen that employment growth in manufacturing mostly reduces GDP per capita (see Table 4).

Table 4 - Regression analysis - log-log models for 10 sectors of economic activity at 8 stages and 2 phases of innovative development

\begin{tabular}{|c|c|c|c|c|c|c|c|c|c|c|c|c|c|c|c|c|c|c|c|c|c|c|c|c|}
\hline & \multicolumn{12}{|c|}{ RESULT } & \multicolumn{12}{|c|}{ PROCESS } \\
\hline & \multicolumn{3}{|c|}{ Leaders } & \multicolumn{3}{|c|}{ Followers } & \multicolumn{3}{|c|}{ Moderate } & \multicolumn{3}{|c|}{ Modest } & \multicolumn{3}{|c|}{ Leaders } & \multicolumn{3}{|c|}{ Followers } & \multicolumn{3}{|c|}{ Moderate } & \multicolumn{3}{|c|}{ Modest } \\
\hline \multicolumn{25}{|c|}{ Dependent variable: In(GDP per capita) (within each stage) } \\
\hline $\begin{array}{l}\text { Independent } \\
\text { variables } \\
\text { In } \\
\text { (Employment in } \\
\text { sector, 2000- } \\
\text { 2011) }\end{array}$ & 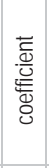 & $\begin{array}{c}\mathrm{p}- \\
\text { value } \\
\text { (Sig.) }\end{array}$ & $\mathrm{R}^{2}$ & 蒙 & $\begin{array}{c}\text { p- } \\
\text { value } \\
\text { (Sig.) }\end{array}$ & $\mathrm{R}^{2}$ & 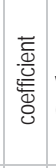 & $\begin{array}{c}\text { p- } \\
\text { value } \\
\text { (Sig.) }\end{array}$ & $\mathrm{R}^{2}$ & 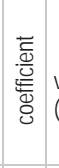 & $\begin{array}{c}\text { p- } \\
\text { value } \\
\text { (Sig.) }\end{array}$ & $\mathrm{R}^{2}$ & 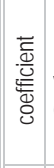 & $\begin{array}{c}\text { p- } \\
\text { value } \\
\text { (Sig.) }\end{array}$ & $\mathrm{R}^{2}$ & 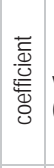 & $\begin{array}{c}p- \\
\text { value } \\
\text { (Sig.) }\end{array}$ & $\mathrm{R}^{2}$ & 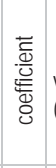 & $\begin{array}{c}\text { p- } \\
\text { value } \\
\text { (Sig.) }\end{array}$ & $\mathrm{R}^{2}$ & 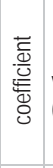 & $\begin{array}{c}\text { p- } \\
\text { value } \\
\text { (Sig.) }\end{array}$ & $\mathrm{R}^{2}$ \\
\hline $\ln (\mathrm{HTM})$ & $\begin{array}{c}- \\
.509\end{array}$ & .091 & .259 & $\begin{array}{c}- \\
.760\end{array}$ & .004. & .577 & .828 & .001 & .686 & .113 & .726 & .013 & .179 & .577 & .032 & $\begin{array}{c}- \\
.582\end{array}$ & .047 & .339 & $\begin{array}{c}- \\
.599\end{array}$ & .040 & .359 & $\begin{array}{c}- \\
.351\end{array}$ & .263 & .123 \\
\hline$\beta_{1}$ & \multicolumn{3}{|c|}{-0.754} & \multicolumn{3}{|c|}{-0.266} & \multicolumn{3}{|c|}{0.715} & \multicolumn{3}{|c|}{-0.130} & \multicolumn{3}{|c|}{0.440} & \multicolumn{3}{|c|}{-0.246} & \multicolumn{3}{|c|}{-1.311} & \multicolumn{3}{|c|}{-0.130} \\
\hline In(MHTM) & $\begin{array}{c}- \\
.561\end{array}$ & .058 & .314 & .750 & .005 & .563 & .915 & .000 & .838 & .663 & .019. & .439 & .807 & .002 & .651 & $\begin{array}{c}- \\
.544\end{array}$ & .068 & 296 & $\begin{array}{c}- \\
.508\end{array}$ & 0.92 & .258 & $\begin{array}{c}- \\
.543\end{array}$ & .068 & .295 \\
\hline$\beta_{1}$ & \multicolumn{3}{|c|}{-0.898} & \multicolumn{3}{|c|}{-0.377} & \multicolumn{3}{|c|}{0.468} & \multicolumn{3}{|c|}{-1.499} & \multicolumn{3}{|c|}{1.705} & \multicolumn{3}{|c|}{-0.367} & \multicolumn{3}{|c|}{-1.260} & \multicolumn{3}{|c|}{-0.298} \\
\hline In(MLTM) & $\begin{array}{c}- \\
423\end{array}$ & .171 & .179 & $\begin{array}{c}- \\
.725\end{array}$ & .008 & .525 & .947 & .000 & .896 & $\begin{array}{c}- \\
.565\end{array}$ & .055 . & .320 & .618 & .032 & .381 & $\begin{array}{c}- \\
.459\end{array}$ & .133 & 211 &. & .279 & .116 & $\begin{array}{c}- \\
.744\end{array}$ & .006 & .553 \\
\hline$\beta_{1}$ & \multicolumn{3}{|c|}{-0.607} & \multicolumn{3}{|c|}{-0.427} & \multicolumn{3}{|c|}{0.472} & & -2.717 & & & 1.450 & & & -0.326 & & & -0.835 & & & -0.648 & \\
\hline $\ln (\mathrm{LTM})$ & $\begin{array}{c}- \\
.769\end{array}$ & .003 & .591. & $\begin{array}{c}- \\
.797\end{array}$ & .002 . & .635 & 684 & .014 & 468 & .339 & .281 & .115 & 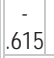 & .033 & .378 & $\begin{array}{c}- \\
679\end{array}$ & .015 & .461. & 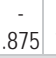 & .000 & .766 & $\begin{array}{c}- \\
.412\end{array}$ & .184 & .169 \\
\hline$\beta_{1}$ & & -0.490 & & & -0.363 & & & 0.538 & & & -0.670 & & & -0.871 & & & -0.280 & & & -0.879 & & & -0.199 & \\
\hline In(HTKIS) & .862 & .000 & .742 . & .826 & .001. & .681 & .913 & .000 & .833 & .765 & .004. & .585 & .883 & .000 & .779 & .779 & .003 . & .607. & .922 & .000 & .849 & .118 & .715 & .014 \\
\hline$\beta_{1}$ & & 0.835 & & & 0.897 & & & 0.429 & & & 2.081 & & & 0.820 & & & 0.702 & & & 1.236 & & & 0.018 & \\
\hline
\end{tabular}




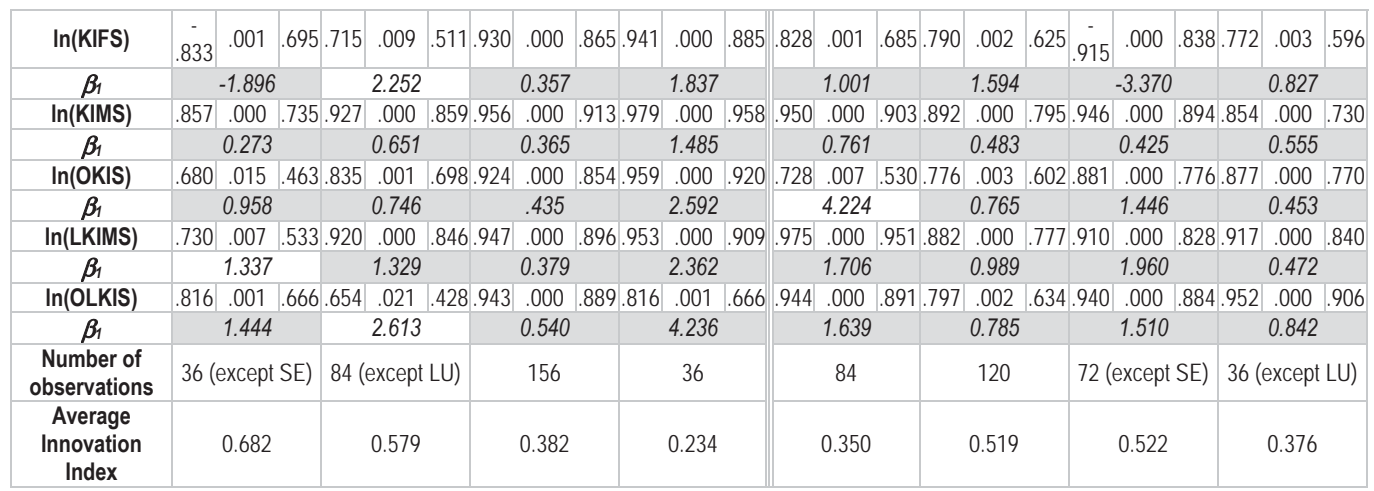

Note: Dark cells indicate on $\beta_{1}$ coefficients for statistically significant models; number of observations - number of countries in each group, 12 years.

Explanation of sectors' abbreviations is available in the Appendix A

Source: authors' calculations in SPSS environment based on data from Eurostat, 2015 a, 2015b; European Commission, 2015

Additionally, specialization that mostly significantly contributes to the growth of GDP per capita (see Table 3) provides sufficient growth rates of GDP per capita only in economies that are at moderate stage of innovative development (Moderate (by result)) or at leaders' stage of process of innovative development (Leaders (by process)). Moreover, authors find that both manufacturing and services are important for growth at these stages (see Table 4). In turn, economies with strong innovative performance or slow innovative development (e.g., Leaders (result), Followers (result), Moderate (process), and Modest (process)) demonstrate that employment growth in sectors of specialization, which closely correlate with GDP per capita, stimulates lower growth rates of GDP per capita (comparing them with other sectors) or even reduces GDP per capita (see Table 4).

Application of regression analysis, particularly a number of nonlinear regression log-log models, allow authors to highlight that despite of absence of clearly visible importance of certain sectors for growth at each stage of innovative development:

- Services have demonstrated dominant positions and brighter contribution to growth of GDP per capita, except the stages Moderate (by result) or Leaders (by process);

- High-tech and knowledge-intensive services have mostly contributed to growth of GDP per capita in economies that are leaders in process of innovative development;

- Specialization of economies modestly contributes to the growth of GDP per capita, especially for economies with high innovative performance or slow innovative development.

However, the data of nonlinear regression log-log models do not allow authors to select a more promising sector for growth at each stage of innovative development. Further analysis presented in the Table 5 using data on GDP per capita and employment in 10 sectors of economic activity provides detailed account on significance of the sectors for growth using linear regression and stepwise method thus excluding statistically insignificant sectors (see Table 5). This, in turn, allow the authors to select those sectors, which mostly contribute to growth and characterize relationship between tested variables.

Results of linear regression presented in the Table 5 also indicate that services (except KIFS) have provided statistically significant impact on GDP per capita more often, despite the stage of innovative development; however, sectors' contribution differs (see Table 5).

For example, the sector HTKIS has contributed positively to the GDP per capita only at the stage Leaders (by result) and the impact was negative for other stages, where the sector have participated in the modelling (Followers (result) Model 2, Followers (process) - Model 4) (see Table 5).

In turn, such services as KIMS have affected GDP per capita at all stages related to result of innovative development (except Leaders (result)) and for stage Followers (process) only. Economies that are at the stage Leaders (result) have experienced significant HTKIS's contribution to the GDP per capita. One more bright observation indicates that GDP per capita have experienced impact from KIMS, although, the impact was more significant only at the stage Modest (result). 
Authors found out that economies have focused on the sector KIMS mostly at all stages of innovative performance (result).

The opposite tendency in terms of technological intensity is topical for the economies during the process of innovative development. The sector LKIMS have affected GDP per capita in bigger extent in this case. In general, GDP per capita growth has enriched from the services that are less knowledge intensive (LKIMS and OLKIS) mostly during the process of innovative development.

Manufacturing weakly participates in formation of GDP per capita in accordance with authors' calculations (see Table 5). High-tech and me-high-tech manufacturing have affected GDP per capita in economies during the process of innovative development only.

Table 5 - Linear regression equations for 10 sectors of economic activity in 2 phases and at 8 stages of innovative development

\begin{tabular}{|c|c|c|c|c|c|}
\hline \multicolumn{3}{|l|}{ RESULT } & \multicolumn{3}{|l|}{ PROCESS } \\
\hline \multicolumn{2}{|l|}{ Leaders } & \multirow{3}{*}{$\begin{array}{l}y=4809.07+21.39 x_{(H T K I S)} \\
R=.862 ; R^{2}=.744 ; \\
\text { Sig. }=.000 ; \text { Sig. }\left(x_{(\text {HTKIS })}\right)=.000 \\
y=10080.42+2.76 x_{(K I M S)} \\
R=.923 ; R^{2}=.851 ; \text { Sig. }=.000 ; \\
\text { Sig. }\left(x_{(\text {KIMS })}=.000\right.\end{array}$} & \multicolumn{2}{|l|}{ Leaders } & $\begin{array}{l}y=-5778.77+4.21 x_{(L K I M S)} \\
R=.972 ; R^{2}=.945 ; \text { Sig. }=.000 ; \text { Sig. }\left(x_{(L K I M S)}\right)=.000\end{array}$ \\
\hline \multirow{4}{*}{ Followers } & \multirow[t]{2}{*}{ Model 1} & & \multirow{4}{*}{ Followers } & Model 1 & $\begin{array}{l}y=12851.62+1.39 x_{(\text {KIMS })} \\
R=.885 ; R^{2}=.783 ; \text { Sig. }=.000 ; \text { Sig. }\left(x_{(\text {KIMS })}\right)=.000\end{array}$ \\
\hline & & & & Model 2 & $\begin{array}{l}y=-989.72+2.23 x_{(\text {KIMS })}+6.33_{(H T M)} \\
R=.940 ; R^{2}=.884 ; \text { Sig. }=.000 ; \text { Sig. }\left(x_{(\text {(IIMS) })}=.000 ; \text { Sig. }\right. \\
\left(x_{(\text {HTM })}\right)=.021\end{array}$ \\
\hline & \multirow[t]{2}{*}{ Model 2} & \multirow{2}{*}{$\begin{array}{l}y=20687.22+5.37 x_{(K I M S)}- \\
11.77 x_{(H T K I S)} \\
R=.955 ; R^{2}=.912 ; \text { Sig. }=.000 ; \\
\text { Sig. }\left(x_{(K I M S)}\right)=.001 ; \text { Sig. } \\
\left(x_{(H T K I S)}\right)=.034\end{array}$} & & Model 3 & 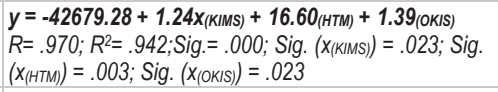 \\
\hline & & & & Model 4 & $\begin{array}{l}y=-33013.09+2.09 x_{(\text {KIMS })}+15.23_{(\text {HTM })}+1.35_{(\text {OKIS })}- \\
4.50_{(\text {HTKIS })} \\
R=.986 ; R^{2}=.973 ; \text { Sig. }=.000 ; \text { Sig. }\left(x_{(\text {KIMS })}=.002 ; \text { Sig. }\right. \\
\left(x_{(\text {(HTM })}\right)=.001 ; \text { Sig. }\left(x_{(\text {(OKIS })}\right)=.007 ; \text { Sig. }\left(x_{(\text {HTKIS })}\right)=.025\end{array}$ \\
\hline \multicolumn{2}{|l|}{ Moderate } & $\begin{array}{l}y=8033.35+1.84 x_{(K I M S)} \\
R=.949 ; R^{2}=.900 ; \text { Sig. }=.000 ; \\
\text { Sig. }\left(x_{(\text {KIMSS) })=.000}\right.\end{array}$ & \multicolumn{2}{|l|}{ Moderate } & $\begin{array}{l}y=-11093.51+10.74 x_{(O L K I S)} \\
R=.935 ; R^{2}=.873 ; \text { Sig. }=.000 ; \text { Sig. }\left(x_{(O L K I S)}\right)=.000\end{array}$ \\
\hline \multirow{4}{*}{\multicolumn{2}{|c|}{ Modest }} & $\begin{array}{l}y=-1894.59+21.79 x_{(\text {(KIMS) }} \\
R=.973 ; R^{2}=.946 ; \text { Sig. }=.000 ;\end{array}$ & \multirow{4}{*}{ Modest } & Model 1 & $\begin{array}{l}y=2171.39+12.03 x_{(\text {OLKIS })} \\
R=.947 ; R^{2}=.897 ; \text { Sig. }=.000 ; \text { Sig. }\left(x_{(O L K I S)}\right)=.000\end{array}$ \\
\hline & & \multirow[t]{3}{*}{ Sig. $\left(x_{(K I M S)}\right)=.000$} & & Model 2 & $\begin{array}{l}y=-3437.69+15.06 x_{(O L K I S)}+3.38_{(M H T M)} \\
R=.971 ; R^{2}=.942 ; \text { Sig. }=.000 ; \text { Sig. }\left(x_{(\text {OLKIS })}\right)=.000 ; \text { Sig. } \\
\left(x_{(\text {MHTM })}=.025\right.\end{array}$ \\
\hline & & & & Model 3 & $\begin{array}{l}y=-6405.25+8.54 x_{(\text {OLKIS })}+7.47_{(\text {MHTM })}+1.39_{(\text {OKIS })} \\
R=.992 ; R^{2}=.984 ; \text { Sig. }=.000 ; \text { Sig. }\left(x_{(\text {OLKIS })}\right)=.001 ; \text { Sig. } \\
\left(x_{(\text {MHTM })}\right)=.000 ; \text { Sig. }\left(x_{(\text {OKIS })}\right)=.002\end{array}$ \\
\hline & & & & Model 4 & $\begin{array}{l}y=-5309.78+8.02 x_{(O L K I S)}+6.56_{(\text {MHTM })}+1.33_{(O K I S)}- \\
0.88_{(\text {HTKIS })} \\
R=.996 ; R^{2}=.992 ; \text { Sig. }=.000 ; \text { Sig. }\left(x_{(\text {OLKIS) })}=.000 ; \text { Sig. }\right. \\
\left(x_{(\text {MHTM) }}\right)=.000 ; \text { Sig. }\left(x_{(\text {OKIS) }}\right)=.001 ; \text { Sig. }\left(x_{(\text {HTKIS) })}=.030\right.\end{array}$ \\
\hline
\end{tabular}

Note: GDP per capita $(y)$ - dependent variable, employment in 10 sectors of economic activity $(x)$ - independent variables; Method - Stepwise; $n=12, n$-years (from 2000 to 2011). Explanation of sectors' abbreviations is available in the Appendix A

Source: authors' calculations in SPSS environment based on Eurostat, 2015a, 2015b

The models indicate that not one, but several sectors have affected GDP per capita. Authors offer summary of linear regression in the Table 6 . The data present the sectors that were detected, as statistically significant for growth of GDP per capita (see Table 6).

Authors found similarity between economies in terms of sectors that mostly contribute to GDP per capita growth despite the stage of innovative development. Mostly, services have affected GDP per capita. Additionally, technological intensity of services has great importance. For example, the sector KIMS have dominated in economies divided into stages in accordance to data about result of innovative development. In turn, the sector KIMS and more often less knowledge intensive services, as OLKIS and LKIMS, have affected GDP per capita in economies during the process of innovative development. Additionally, manufacturing, especially high-tech and me-high-tech, have contributed to GDP per capita during the process of innovative development. Valuable observation concerning the sector HTKIS indicate that the sector positively have affected GDP per capita only in economies with high innovative performance (Leaders (result)) and 
provides negative impact on GDP per capita in other economies (see Table 5).

Is it possible to conclude that sectors have affected positively GDP per capita at each stage of innovative development?

Table 6 - Sectors that mostly contribute to growth at different phases and stages of innovative development, in accordance with statistically significant data

\begin{tabular}{|c|c|c|c|c|c|}
\hline \multicolumn{3}{|l|}{ RESULT } & \multicolumn{3}{|l|}{ PROCESS } \\
\hline \multicolumn{2}{|l|}{ Leaders } & \multirow{3}{*}{$\begin{array}{l}\text { HTKIS } \\
\text { KIMS }\end{array}$} & \multicolumn{2}{|l|}{ Leaders } & LKIMS \\
\hline \multirow{4}{*}{ Followers } & \multirow[b]{2}{*}{ Model 1} & & \multirow{4}{*}{ Followers } & Model 1 & KIMS \\
\hline & & & & Model 2 & $\begin{array}{l}\text { KIMS } \\
\text { HTM }\end{array}$ \\
\hline & \multirow[b]{2}{*}{ Model 2} & \multirow[b]{2}{*}{$\begin{array}{l}\text { KIMS } \\
\text { HTKIS }\end{array}$} & & Model 3 & $\begin{array}{l}\text { KIMS } \\
\text { HTM } \\
\text { OKIS }\end{array}$ \\
\hline & & & & Model 4 & $\begin{array}{l}\text { KIMS } \\
\text { HTM } \\
\text { OKIS } \\
\text { HTKIS }\end{array}$ \\
\hline \multicolumn{2}{|l|}{ Moderate } & KIMS & \multicolumn{2}{|l|}{ Moderate } & OLKIS \\
\hline \multirow{4}{*}{ Modest } & & \multirow{4}{*}{ KIMS } & \multirow{4}{*}{ Modest } & Model 1 & OLKIS \\
\hline & & & & Model 2 & $\begin{array}{l}\text { OLKIS } \\
\text { MHTM }\end{array}$ \\
\hline & & & & Model 3 & $\begin{array}{l}\text { OLKIS } \\
\text { MHTM } \\
\text { OKIS }\end{array}$ \\
\hline & & & & Model 4 & $\begin{array}{l}\text { OLKIS } \\
\text { MHTM } \\
\text { OKIS } \\
\text { HTKIS }\end{array}$ \\
\hline
\end{tabular}

Note: Explanation of sectors' abbreviations is available in the Appendix A

Source: elaborated by the authors based on calculations presented in the Table 5

Positive trends of GDP per capita at all stages of innovative development (see Figure 1) allows authors to suppose that the findings have a positive context, i.e. the sectors that mostly have contributed to the growth of GDP per capita have encouraged GDP per capita growth. However, the most pronounced increase of GDP per capita was observed for economies at the stages Modest (result) and Leaders (process) (respectively in 1.71 and 1.40 times), thus indicating that less knowledge intensive services seriously have contributed to the GDP per capita as well.

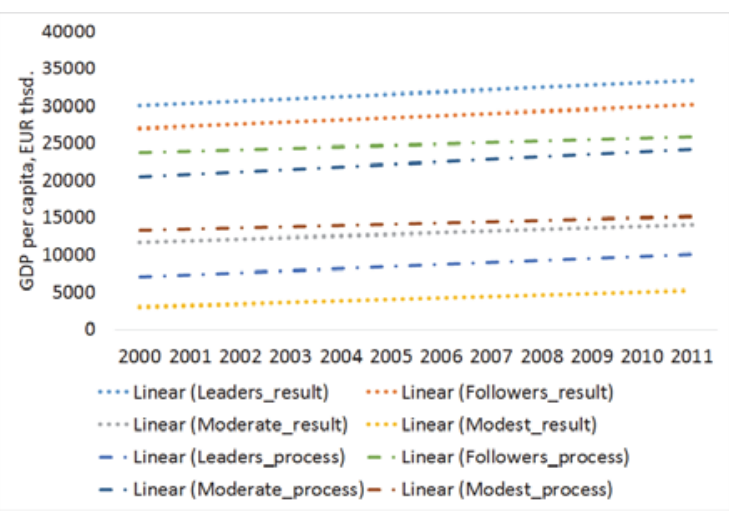

Figure 1. Linear trends of evolution of GDP per capita at different phases and stages of innovative development in 20002011, EUR thsd.

Source: Elaborated by authors based on Eurostat, 2015a 
What can authors conclude? Analysis of sectors' contribution to GDP per capita, taking into account technological intensity of the sectors and different stages of innovative development, taking into account result and process of innovative development, underlines that technological intensity of the sectors matters mostly for different phases of innovative development, i.e. result and process, rather than for different stages within the phases. On the other hand, it seems that countries with high innovative performance and fast its growth could focus on increasing of meaning of technologically higher intensive sectors in bigger extent. However, concept of smart specialization indicates that each economy should highlight the potential and advantages not copying and pursuing widely spread aims in the field of high technologies. On the other hand, meaning of dominated sectors questions the brightly expressed aims to pursue improvements in innovative performance.

\section{Conclusion}

The choice in favour to certain sector (-s) for enriching the future growth is widely debated in the fields of science and practice. Manufacturing mostly is recognized as an engine for growth (e.g. Kaldor, 1966; Marelli, 2004; Gallego, Marroto, 2015 etc.), however, services become more important for growth as well (e.g. Kemeny, Stroper, 2015). Authors have contributed to the debates using the case study of the European Union and focusing on different stages of innovative development (Leaders, Followers, Moderate, Modest (European Commission, 2015)) within the phases of innovative development, i.e. result (level of innovative development) and process (growth rates of innovative development). The interest to focus on sectors' impact on growth at different stages and phases of innovative development finds roots in bright difference by innovative development between economies in European Union as well as in similarity by sectoral composition and by aims set for the future growth. Moreover, scientific findings and practical solutions underline the rising tendency to prioritize not only high-tech sectors, but local needs and priorities as well (even in traditional sectors). For example, absence of universal set of sectors for better growth (e.g. Landabasso, 2012) and dependency on complex activities in terms of reaching leading positions of high-tech sectors (e.g. Tiits et al., 2015) requires focusing on already strong or promising sectors, which could gain from innovation (e.g. Landabaso, 2012; European Commission, 2010; 2014). This makes understanding of 'correctness' of stimuli for growth difficult.

Authors of the paper have tried to make clear the evolution of significance of sectors of economic activity among different phases and stages of innovative development. The research findings allow authors to conclude that contribution of sectors of economic activity mostly differs between phases (result and process of innovative development) rather than between different stages of innovative development within each phase.

For example, economies mostly specialize in manufacturing during the fast catching-up and in services during the experiencing high level of innovative development. In general, authors have found that specialization correlates with GDP per capita during the process of accelerating innovative development and in economies that experience moderate or modest level of innovative development. This underlines the importance of 'correct' choice in favour of certain sector (-s) of economic activity. This finds reflection in economies' behaviour also. For example, economies with high level of innovative development have cut specialization in all sectors, including high-tech and knowledge-intensive sectors; in turn, economies with fast improvements of innovative development have boosted specialization in all sectors, even in low-tech and less knowledge-intensive sectors. Authors have supposed the similar significance of all sectors for economies, despite of stage of innovative development, taking into account the above-mentioned tendencies. The supposition was tested by application of number of nonlinear and linear regression models.

The results of regression analysis imply similarity of sectors' contribution to growth, especially for the phase of result. Economies during the phase of process differ between stages of innovative development in bigger extent. Services mostly affect GDP per capita for economies at both phases and services' technological intensity is important. For example, high-tech services contribute to growth only in economies that are at Leaders' stage of level of innovative development, and even reduce growth rates for other economies. One more example underlines that manufacturing participates significantly in formation of GDP per capita only during the process of innovative development. In terms of specialization, authors have detected that specialization, which correlates with GDP per capita, stimulates lower growth rates or even reduces it in economies that are at high or moderate stage of innovative development.

Is there a more promising sector for growth in innovative and less-innovative economy? The analysis provided by the authors discovers that services mostly contribute to growth at all stages of innovative development. Similarity between economies and meaning of dominant sectors has lead to supposition that innovative achievements still weakly contribute to sectors' contribution to growth what will continue to question the launching of smart specialization strategies. However, the results were reached at 10 sectors' aggregation and more detailed classification of economic activities could offer brighter difference between economies in terms of specialization. On the other hand, authors have focused on 
growth paying attention to innovative development and technological intensity of the sectors. These factors cannot be divided in more detailed aggregation and thus to contribute to the results in bigger extent or in different manner.

The research results set the number of issues for the future research also. For example, it would be of interest to understand (a) the reasons for changing the priorities in terms of dominant sectors after transition to higher stages of innovative development; (b) non-core positions of manufacturing, especially high-tech manufacturing in formation of GDP per capita, even in economies that are leaders by innovative development; (c) possibilities of economies to compete on the basis of similar dominant sectors.

\section{Acknowledgment}

The National Research Program 5.2. "Economic transformation, smart growth, governance and legal framework for sustainable development of the state and society - a new approach to the creation of a sustainable learning community" (EKOSOC-LV) supported the research.

\section{References}

Ali, A. K. (2014). Explaining Smart Growth Applications: Lessons Learned from the US Capital Region. Urban Studies, 51(1), 116-135.

Arhipova, I. Bālinga S. (2003). Statistika ekonomikā. [Statistics in Economics] Datorzinību centrs [Centre of Computer Knowledge].

Badunenko, O., Fritsch, M., Stephan, A. (2006). What Determines the Technical Efficiency of a Firm? The Importance of Industry, Location and Size. Arbeits- und Diskussionspapiere der Wirtschaftswissenschaftlichen Fakultat der Fridrich-Schiller-Universitat Jena.

Coenen, L., Moodysson, J., Martin, H. (2015). Path Renewal in Old Industrial Regions: Possibilities and Limitations for Regional Innovation Policy. Regional Studies, 49(5), 850-865.

Dosi, G., Nelson, R. R. (2010). Technical change and industrial dynamics as evolutionary processes. Handbook of the Economics of Innovation 1 (1C), 51-127.

European Commission, (2010), Communication from the Commission to the European Parliament, the Council, the European Economic and Social Committee and the Committee of the Regions. Regional Policy contributing to smart growth in Europe 2020, SEC(2010) 1183. [Online] Available: http://ec.europa.eu/regional_policy/sources/docoffic/official/communic/smart_growth/comm 2010_553_en.pdf (November 30, 2015).

European Commission, (2014), Smart Specialization and Europe's Growth Agenda. [Online] Available: http:/lec.europa.eu/regional_ policy/sources/docgener/studies/pdf/smart_spec_growth_agenda.pdf (November 30, 2015).

European Commission, (2015), Innovation Union Scoreboard 2015. [Online] Available: http://ec.europa.eu/growth/industry/innovation/ facts-figures/scoreboards/files/ius-2015_en.pdf (November 30, 2015).

Eurostat, (2014), Eurostat Indicators of High-tech Industry and knowledge-intensive services. Annex 3 - High-tech Aggregation by NACE Rev. 2. [Online] Available: http://ec.europa.eu/eurostat/cache/metadata/Annexes/htec_esms_an3.pdf (November 30, 2015).

Eurostat, (2015a), GDP per capita - annual Data [nama_aux_gph]. [Online] Available: http://ec.europa.eu/eurostat/data/database (November 30, 2015).

Eurostat, (2015b), National Accounts by 64 branches - employment data [nama_nace64_e]. [Online] Available: http://ec.europa.eu/ eurostat/data/database (November 30, 2015).

Fritsch, M., Slavtchev, V. (2011). Determinants of the Efficiency of Regional Innovation Systems. Regional Studies, 45(7), 905-918.

Gallego, J., Maroto, A. (2015). The Specialization in Knowledge-Intensive Business Services (KIBS) across Europe: Permanent CoLocalization to Debate. Regional Studies, 49(4), 644-664.

Huggins, R., Strakova, L. (2012). Knowledge-based Economic Development in Emerging Regions: Policy Issues and Implications in the Balkan Peninsula. Regional Studies, 46(7), 961-975.

Kaldor, N. (1966). Causes of the slow rate of economic growth of the United Kingdom. Cambridge University Press. Cambridge.

Karo, E., Kattel, R. (2011). Economic development and evolving state capacities in Central and Eastern Europe: can "smart specialization" make a difference? Journal of Economic Policy Reform, 18(2), 172-187.

Kemeny, T., Storper, M. (2015). Is Specialization Good for Regional Economic Development? Regional Studies, 49(6), 1003-1018.

KPMG, (2015), Future state: Australian manufacturing and smart specialization. [Online] Available: https://www.kpmg.com/AU/en/lssues AndInsights/ArticlesPublications/manufacturing-executives-forum-insights/Documents/australian-manufacturing-smartspecialisation-june-2015.pdf (November 30, 2015).

Landabaso, M, (2012), Research and Innovation Strategies for Smart Specialization. [Online] Available: https://www.unece.org/fileadmin/ DAM/ceci/documents/2012/ICP/TOS_ICP/Landabaso.pdf (November 30, 2015).

Landabaso, M. (2014). Guest editorial on research and innovation strategies for smart specialisation in Europe: Theory and practice of new innovation policy approaches. European Journal of Innovation Management, 17(4), 378-389.

Laursen, K, (1998), How structural change differs, and why it matters (for economic growth). DRUID working paper, No. 98-25. Danish Research Unit for Industrial Dynamics. [Online] Available: http://econpapers.repec.org/paper/aalabbswp/98-25.htm http://www.druid.dk/laursen/papers/schump.pdf (November 30, 2015). 
Lerro, A., Jacobone, F. (2014). Smart growth, smart specialisations strategies and impact of the technological districts: The moderating effect of business, geographical and institutional factors. International Journal of Knowledge-Based Development, 5(3), $221-237$.

Marelli, E. (2004). Evolution of employment structures and regional specialisation in the EU. Economic Systems, 28, 35-59.

Maurseth, P. B. (2001). Convergence, geography and technology. Structural Change and Economic Dynamics, 12(3), $247-276$.

McCann, P., Ortega-Argiles, O. (2015). Smart Specialization, Regional Growth and Applications to European Union Cohesion Policy. Regional Studies, 49(8), 1291-1302.

Muscio, A., Reid, A., Rivera Leon, L. (2015). An empirical test of the regional innovation paradox: can smart specialisation overcome the paradox in Central and Eastern Europe? Journal of Economic Policy Reform, 18(2), 153-171.

Naldi, L., Nilsson, P., Westlund, H., \& Wixe, S. (2015). What is smart rural development? Journal of Rural Studies, 40(01), 90-101.

Noseleit, F. (2015). The role of entry and market selection for the dynamics of regional diversity and specialization. Regional Studies, 49(1), 76-94.

O'Donoghue, D., Townshend, I. J. (2005). Diversification, Specialization, Convergence and Divergence of Sectoral Employment Structures in the British Urban System, 1991-2001. Regional Studies, 39(5), 585-601.

Quatraro, F. (2009). Innovation, structural change and productivity growth: evidence from Italian regions, 1980-2003. Cambridge Journal of Economics, 33(5), 1001-1022.

Radosevic, S, (2014), Industrial and Technology Restructuring in CEECS: key insights and policy issues. Presented at „Cohesion in the new EU member states: catching-up, structural change and the role of trade and FDI”, 30 October, 2014. The Vienna Institute for International Economic Studies (wiiw). [Online] Available: http://wiiw.ac.at/industrial-and-technology-restructuring-in-ceecs-keyinsights-and-policy-issues-p-3388.html (November 30, 2015).

Romano, A., Passiante, G., Vecchio, P. D., Secundo, G. (2014). The innovation ecosystem as booster for the innovative entrepreneurship in the smart specialisation strategy. International Journal of Knowledge-Based Development, 5(3), 271-288.

Thakur, S, K, (2011), Fundamental economic structure and structural change in regional economies: a methodological approach. Region et Developpement, Nr. 33. [Online] Available: http://region-development.univ-tln.fr/en/pdf/R33/Thakur.pdf (November 30, 2015).

Tiits, M., Kalvet, T., Mürk, I. (2015). Smart specialisation in cohesion economies. Journal of the Knowledge Economy, 6(2), 296-319.

UNIDO, UNU-MERIT, (2012), Structural Change, Poverty Reduction and Industrial Policy in the BRICS. [Online] Available: http://www10.iadb.org/intal/intalcdi/PE/2013/10846.pdf (November 30, 2015).

Weterings, A., Marsili, O. (2015). Spatial concentration of industries and new firm exits: does this relationship differ between exits by closure and by M\&A. Regional Studies, 49(1), 44-58.

Appendix A. Authors' used abbreviation for sectors

\begin{tabular}{|c|l|}
\hline HTM & High-tech manufacturing \\
\hline MHTM & Medium-high-tech manufacturing \\
\hline MLTM & Medium-low-tech manufacturing \\
\hline LTM & Low-tech manufacturing \\
\hline HTKIS & High-tech knowledge-intensive services \\
\hline KIFS & Knowledge-intensive financial services \\
\hline KIMS & Knowledge-intensive market services \\
\hline OKIS & Other knowledge-intensive services \\
\hline LKIMS & Less knowledge-intensive market services \\
\hline OLKIS & Other less knowledge-intensive services \\
\hline
\end{tabular}

Source: authors' abbreviation based on data Eurostat, 2014

Appendix B. Distribution of countries in accordance with RESULT (Innovation Index)

\begin{tabular}{|l|l|}
\hline INNOVATION LEADERS & $\mathrm{SE}, \mathrm{DK}, \mathrm{FI}, \mathrm{DE}$ \\
\hline INNOVATION FOLLOWERS & $\mathrm{NL}, \mathrm{LU}, \mathrm{UK}, \mathrm{IE}, \mathrm{BE}, \mathrm{FR}, \mathrm{AT}, \mathrm{SI}$ \\
\hline MODERATE INNOVATORS & $\mathrm{EE}, \mathrm{CZ}, \mathrm{CY}, \mathrm{IT}, \mathrm{PT}, \mathrm{MT}, \mathrm{ES}, \mathrm{HU}, \mathrm{EL}, \mathrm{SK}, \mathrm{HR}, \mathrm{PL}, \mathrm{LT}$ \\
\hline MODEST INNOVATORS & $\mathrm{LV}, \mathrm{BG}, \mathrm{RO}$ \\
\hline
\end{tabular}

Source: European Commission, 2015

Appendix C. Distribution of countries in accordance with PROCESS (growth performance of Innovation Index)

\begin{tabular}{|l|l|}
\hline INNOVATION LEADERS (growth rates $>2.0 \%$ ) & LV, BG, MT,SI, CZ, EE, LT \\
\hline INNOVATION FOLLOWERS (growth rates 1.1-1.9\%) & $\mathrm{SK}, \mathrm{DK}, \mathrm{NL}, \mathrm{UK}, \mathrm{IT}, \mathrm{PT}, \mathrm{IE}, \mathrm{HU}, \mathrm{FR}, \mathrm{BE}$ \\
\hline MODERATE INNOVATORS (growth rates 0.1-1.0\%) & $\mathrm{PL}, \mathrm{HR}, \mathrm{AT}, \mathrm{DE}, \mathrm{SE}, \mathrm{EL}, \mathrm{FI}$ \\
\hline MODEST INNOVATORS (growth rates $\leq 0.0 \%$ ) & $\mathrm{LU}, \mathrm{CY}, \mathrm{ES}, \mathrm{RO}$ \\
\hline
\end{tabular}

Source: authors' distribution in to the stages based on data European Commission, 2015 
Appendix D. Growth of GDP per capita (percentage) as result of sectoral employment growth (1.00\%), $\beta_{1}$ coefficient of statistically significant models (for more detailed information see Table 4)

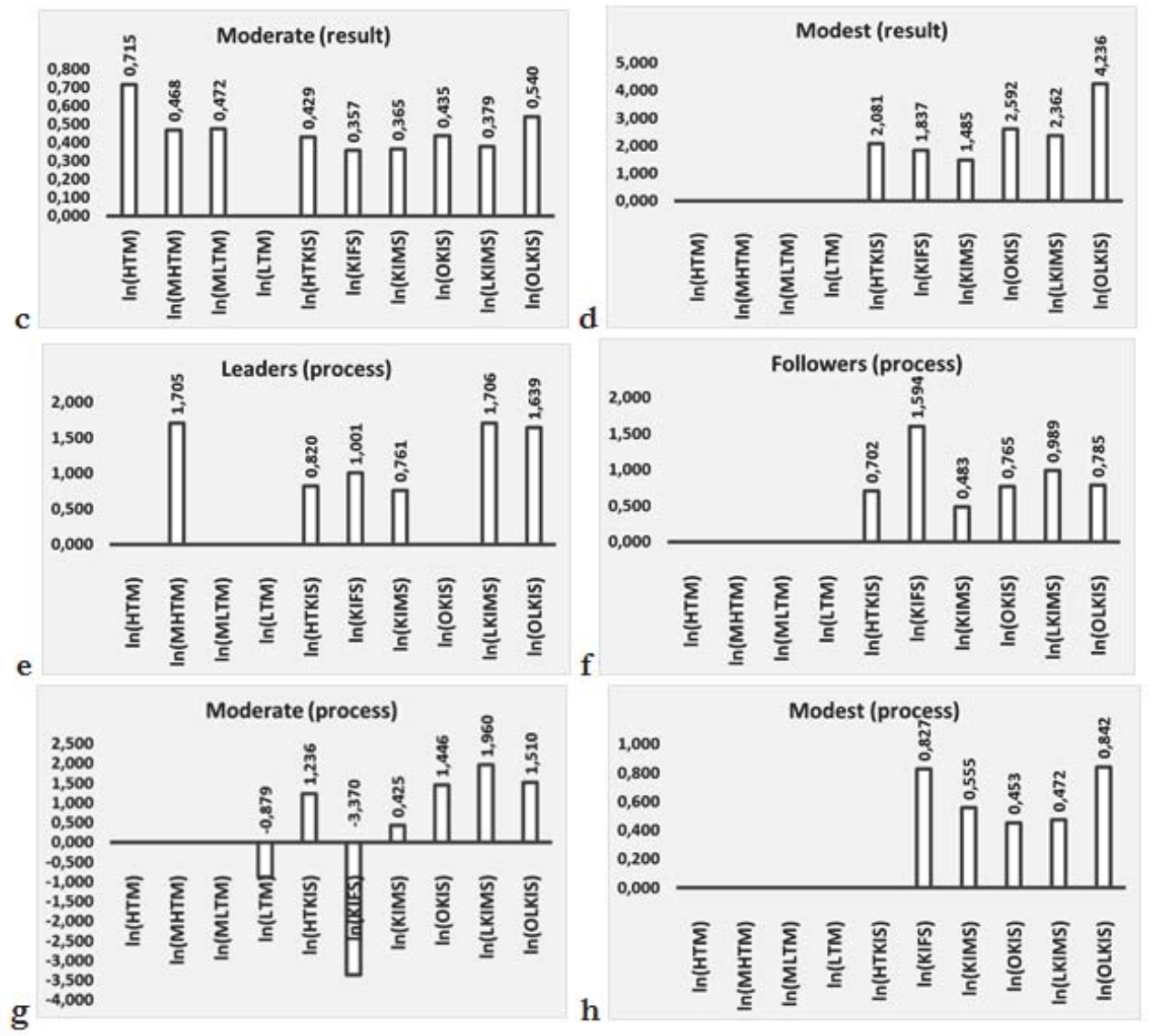

Source: Authors' calculations based on Eurostat, 2015a, 2015b 